\title{
Quantitative assessment of safety and health risks in HAZMAT road transport using a hybrid approach: a case study in Tehran
}

\author{
Iraj Mohammadfam¹, Omid Kalatpour ${ }^{2}$, Kamran Gholamizadeh ${ }^{3 *}$
}

1 Department of Occupational Health and Safety Engineering, Faculty of Health, Hamedan

University of Medical Sciences, Hamedan, Iran https://orcid.org/0000-0003-2460-2789

2 Department of Occupational Health and Safety Engineering, Faculty of Health, Hamedan

University of Medical Sciences, Hamedan, Iran https://orcid.org/0000-0003-0235-4593

3 (*Corresponding author) Department of Occupational Health and Safety Engineering, Faculty

of Health, Hamedan University of Medical Sciences, Hamedan, Iran

P.O. Box_4171-65175, Hamadan, Iran, Tel: +989186575022

Ka.gholamizadeh@edu.umsha.ac.ir, https://orcid.org/0000-0003-2335-0276

Appendix $C$, the names of some of the most prominent safety experts consulted in this study and the subject of their consultation

\begin{tabular}{|c|c|c|}
\hline Name & Expertly area & subject of consultation \\
\hline Mirzaie. M & Risk assessment & $\begin{array}{c}\text { Selection of study nodes } \\
\text { Preparation of fuzzy system guide tables } \\
\text { Final risk assessment }\end{array}$ \\
\hline Ghasemi. F & quantitative Risk assessment & Mapping Bowtie Diagram in Bayesian Network \\
\hline $\begin{array}{l}\text { HSE Fam } \\
\text { Company }\end{array}$ & $\begin{array}{c}\text { Team of Road Safety Experts ( } 20 \\
\text { experts) }\end{array}$ & $\begin{array}{c}\text { Determine the probabilities of the Bowtie diagram } \\
\text { and the Bayesian network }\end{array}$ \\
\hline Asari. J & Industrial Toxicologist & $\begin{array}{c}\text { Determination and Classification of Health Risk } \\
\text { Parameters in Fuzzy System }\end{array}$ \\
\hline Tapak. L & Biostatistics expert & $\begin{array}{c}\text { Determination of fuzzy system type in health risk } \\
\text { assessment and calculate the "SCF" }\end{array}$ \\
\hline
\end{tabular}


